\title{
Airborne Fine Particulate Emissions from Construction Activities
}

\author{
Carolyn Payus, Lai Yu Mian, and Norela Sulaiman
}

\begin{abstract}
Construction activities contribute a significant source of airborne particulate matter (PM) which causing substantial impact on air quality. This study is conducted to investigate the ambient particulate matter concentration at the construction jobsite for newly shop lot 5 -storeys building in Kota Kinabalu, Malaysia. The study focusing on coarse and fine airborne particulate sizes which involved $\mathbf{P M}_{0.3}, \mathbf{P M}_{0.5}, \mathbf{P M}_{1}$ and $\mathbf{P M}_{2}$, thus to evaluate the meteorological factors namely on relative humidity, temperature and wind speed around the construction site during construction activities on PM concentrations. The study is carried out within two different construction phases to evaluate the PM emissions that sourced from the construction activities. Phase 1 is the preliminary stage of the project plan where site preparation activities are carried out, while Phase 2 is the early stage of the project plan where the superstructure construction activities will be involved. Results showed that the concentration of particulate matter collected in Phase 2 is found higher than in Phase $\mathbf{1}$, as more extensive construction activities are being carried out in Phase 2 . The meteorological conditions including temperature, relative humidity and wind speed are also found to be able influenced the characterization of PM according to their sizes. Mitigation and controlling measures to alleviate the emissions of construction activities can be adopted and improved in order to reduce the atmospheric pollution that elicited by PM.
\end{abstract}

Index Terms-Airborne particulate matter (PM), construction activity, coarse and fine particulate size, $\mathbf{P M}_{\mathbf{0 . 3}}$, $\mathbf{P M}_{0.5}, \mathbf{P M}_{1}, \mathbf{P M}_{2}$.

\section{INTRODUCTION}

The concentration of particulate matter in construction site is generally higher than the background concentration as mention in [1]-[3]. The [1] has found that the area mostly influenced by the superstructure construction activities is most environmentally impacted by the PM concentration. Characterization of PM is influenced by the meteorological conditions (humidity, wind speed, temperature and rainfall). Another study shows major airborne $\mathrm{PM}_{2.5}$ emissions are related to automotive exhaust from light-duty, gasoline-powered vehicles rather than to fugitive dust that associated with re-entrained mud/dirt carryout during construction [4]. In addition, dust emission is influenced by the moisture content of road surface materials that resulted from influences of weather factors [5]. Meanwhile, [6] found

Manuscript received December 6, 2016; revised February 15, 2017.

Carolyn Payus and Lai Yu Mian are with Faculty of Science and Natural Resources, Universiti Malaysia Sabah (UMS), 88400 Kota Kinabalu, Malaysia (e-mail: cpayus@gmail.com).

Norela Sulaiman is with School of Environmental and Natural Resources, Faculty of Science and Technology, Universiti Kebangsaan Malaysia (UKM), 46300 Bangi, Selangor Darul Ehsan, Malaysia (e-mail: norelaganun@gmail.com). that $\mathrm{PM}_{10}$ emissions episodes arising mainly from building works and road works which manage to cause the exceeding value of the EU Limit, $50 \mu \mathrm{gm}^{-3}$. However, $\mathrm{PM}_{10}$ from these sources mostly does not arise during wet days. According to [7], there are no particulate matter components for which showing unequivocal evidence of zero health impact. Greater emphasis and research attention has focused on the impacts of exposure to fine particulate matter, $\mathrm{PM}_{2.5}$ especially on respiratory and cardiovascular systems [8]. Latest epidemiologic, toxicological, and controlled human exposure studies have evaluated the health impacts have associated with the ambient components of $\mathrm{PM}_{2.5}$. Comprehensive epidemiological studies were included extensive air quality characterization and development of fine particle concentrators to investigate the effects of different components of $\mathrm{PM}_{2.5}$ while conducting toxicology experiments using ambient air. Numerous effects have been associated to the fine particulate matter on cardiovascular systems including cardiovascular mortality. According to researches, particulate matter instigating the cardiovascular mortality effect sourced from crustal or soil or road dust, traffic and wood smoke or vegetative burning sources. The impact of particulate to cardiovascular system is arterial narrowing, ST-segment alteration, increase systemic inflammation, increase or decrease heart rate, red blood cell changes, decrease blood pressure, and increase hospital admissions also mortality [9]-[11].

\section{Methodology}

The study area for this research is located at the construction site in Kota Kinabalu. The project plan involved a 5-storey shop and offices construction. There are 7 blocks of buildings are being constructed. The construction site chosen for this study is an enclosed area which is surrounded by the barriers or the windbreaks. The barriers are the impervious dust screens or sheeting around construction site used to ensure the data collected for the concentration of particulates within the construction site is the on-site emissions devoid of interference as possible. The concentration of particulate matter in the ambient air around the study site is measured by using grab sampling technique. The samplers are collected by the aiding of the Met One Hand Held Particulate Counter (model GT-321). The instrument comes with an iso-kinetic probe which helps to reduce count errors related to the sample flow velocity and the aerodynamics of small particles. The ambient particulate matter that the instrument is able to identified including $\mathrm{PM}_{0.3}$, $\mathrm{PM}_{0.5}, \mathrm{PM}_{1}, \mathrm{PM}_{2}$ and $\mathrm{PM}_{5}$. Wind speed is measured by using Fisher Scientific Traceable Anemometer/Temperature 
(model 15-0780194) of while the relative humidity is measured by using Vaisala HUMICAP Hand-Held Humidity and Temperature Meter (model HM70). Air sampling is conducted during the working hours for duration of 8 hours each day (09:00 to 17:00) during working days. The on-site wind speed is measured concurrently. Sampling is conducted over a 20-mins period for each occasion continuously to obtain a representative data of $\mathrm{PM}_{0.3}, \mathrm{PM}_{0.5}, \mathrm{PM}_{1}$ and $\mathrm{PM}_{2}$. A 4-days period monitoring is carried out within a week for each particular selected dry and wet season. The on-site meteorological parameters including relative humidity, temperature and wind speed are measured concurrently. The air sampling is carried out at the resting area of the construction workers in the construction jobsite. While, the resting time for the construction workers lies between 09:00-09:30, 11:00-12:00 and 14:00-14:30. During sampling, various construction activities that carried out are observed and recorded. The sampling probes of the air monitoring equipment is placed at nose height, which is approximately $1.5 \mathrm{~m}$ vertically above the ground level the and also is kept away from any source of targeted air pollutant. The height of the sampler placed is intended to reflect an approximate 'typical' zone in which individuals inhale and exhale [12].

\section{RESULTS AND DISCUSSIONS}

The average relative humidity in Phase 1 is relatively higher than in Phase 2. In Phase 1, the daily average relative humidity had a range of $66.16 \%$ to $73.37 \%$. The average relative humidity in a week during Phase 1 is (70.04 \pm $6.53) \%$ with minimum value of $60.18 \%$ and maximum value of $89.31 \%$. In Phase 2, the daily average relative humidity had a range of $51.32 \%$ to $62.00 \%$. While, the average relative humidity in a week during Phase 2 is (58.32 \pm 6.69) $\%$ with minimum value of $60.18 \%$ and maximum value is $89.31 \%$. Thus, there is a decrease of 16.73 percent on the average relative humidity in a week from Phase 1 to Phase 2. According to [13], the northeast monsoon season usually commences in early November and ends in March, and Kota Kinabalu has the highest average evaporation rate in the month of April. Thus, Phase 1 which lies between Decembers to January is considered wet season, and Phase 2 has a comparatively lower ambient relative humidity. West and North divisions of Sabah commonly experienced rainfall distributions $60 \%$ above average values. The relative humidity is having strong negative relationships with the average concentration of different sizes of particulate matter. The $\mathrm{R}$ value for the average relative humidity and the average concentration of particulate is range between -0.53749 to -0.78428 . The result obtained showing that $\mathrm{R}=-0.57044$ for $\mathrm{PM}_{0.3}, \mathrm{R}=-0.53749$ for $\mathrm{PM}_{0.5}, \mathrm{R}=-0.78428$ for $\mathrm{PM}_{1}$ and $\mathrm{R}=-0.71944$ for $\mathrm{PM}_{2}$, as correlate with relative humidity based on each sampling day. Relative humidity influencing the particulates and cause the growth of particles which mainly is due to the condensation of water vapor on the particles [14]. Strong negative relationships that shown is due to the effects of humidity on coalescence and settling of suspended particles. Atmospheric moisture helps fine suspended particulates to stick together, forming heavier particulates and eventually fall down [15]. Air temperature data collected in Phase 1 ranged between $25.41{ }^{\circ} \mathrm{C}$ to $32.83{ }^{\circ} \mathrm{C}$ with an average temperature of $(28.96 \pm 1.46){ }^{\circ} \mathrm{C}$. On the other hand, the temperature during Phase 2 recorded ranged about $28.66{ }^{\circ} \mathrm{C}$ to $34.83{ }^{\circ} \mathrm{C}$ with the average temperature of $(31.57 \pm 1.39)^{\circ} \mathrm{C}$. Meanwhile, the temperature in phase 1 is lower than in Phase 2 and experience a rise of nearly $3{ }^{\circ} \mathrm{C}$ from Phase 1 to Phase 2. Higher temperature is recorded during dry season compared to wet season. The changes in temperature may influence the concentration and distribution of air pollutants through direct and indirect processes such as biogenic emissions, change of chemical reaction rates, changes in mixing heights that affect vertical dispersion of pollutants and modification of synoptic flow patterns that control pollutant transport [16]. High temperature is related to stagnant and poor circulation of air masses in higher atmospheric layers and the immobile air masses causing the production and accumulation of pollutants in ambient air [17].

$\mathrm{PM}$ is increase as temperature increase mainly due to the increase of sulphate and total organic aerosol (OA). Temperature rise causing oxidant levels increase and favors $\mathrm{SO}_{2}$ oxidation. Increase in biogenic $\mathrm{VOC}$ emissions and corresponding increase of biogenic and anthropogenic secondary organic aerosol (SOA) increases the total OA [18]. The [19] had introduce an interaction ratio of the particulate matter effects on warm days and non-warm days, and found extra effect of PM during warm days that resulting higher mortality. Effects on respiratory illness are higher for age group of $15-74$ years old during warm days. Temperature modifies the impact of particulate pollution on death, and the risk on daily mortality is increased on hot days [20]. The ambient temperature and the relative humidity having a strong negative relationship with the value of $\mathrm{R}=-0.8943$. Thus, it is well symbolized that higher temperature carries along with lower relative humidity which is the phenomenon occurred during Phase 1, the drier season; lower temperature carries along higher relative humidity which is the phenomenon occurred during Phase 2, the wet season. Moisture holding capacity of air depends on the atmospheric temperature and it increases with increasing air temperature. As the moisture holding capacity increases, the ambient relative humidity decreases, as no moisture is added to the atmosphere. The relative humidity goes down because warmer air can hold more moisture than colder air. The increase of ambient relative humidity lowers the amount of solar radiation that reaching the surface of the Earth. The air absorbed the heat from the solar radiation, causing the reduction of air temperature nearer to the Earth's surface [21]. This will result the air layer nearer to the surface of the earth becomes colder than the upper layers. The average wind speed for Phase 1 is relatively higher than in Phase 2. Average wind speed collected in Phase 1 is $(3.6 \pm 1.83) \mathrm{m} / \mathrm{s}$, and showing $(2.8 \pm 1.05) \mathrm{m} / \mathrm{s}$ in Phase 2 . The wind speed in Phase 1 is range with $(0.0-7.3) \mathrm{m} / \mathrm{s}$ while $(0.2-5.5) \mathrm{m} / \mathrm{s}$ in Phase 2. Phase 1 presented higher wind speed value which indicates that, the winds are stronger during Phase 1 than during Phase 2 as the northeast monsoon commences [22]. On the whole, wind speed shown negative relationships with average concentration of different sizes of PM. The R value for average wind speed and average concentration of PM 
range is from -0.27928 to -0.57437 . Result obtained showing strong relationship on $\mathrm{PM}_{1}$ and $\mathrm{PM}_{2}$, which $\mathrm{R}=-0.57437$ for $\mathrm{PM}_{1}$ and $\mathrm{R}=-0.53926$ for $\mathrm{PM}_{2}$. For $\mathrm{PM}_{0.3}$ and $\mathrm{PM}_{0.5}$, the relationship is considered weak as $\mathrm{R}$ has value of -0.30480 and -0.27928 . The wind speed is not showing strong relationship indicated by the low $\mathrm{R}$-squared value. Wind with diverse speed and direction is normally accompanied by air mass transport where lower wind speed is favorable for the aggregation of particles. At low wind speed, stagnation allows locally generated pollutants [1]. Thus, the poor dispersion causing the concentration of PM is higher during lower atmospheric wind speed.

The concentration of particulate matter in different sizes is obtained at Phase 1 and Phase 2 respectively. On the whole, Fig. 1-4 have shown significantly that the concentration of particulate matter is relatively higher in Phase 2. The daily average concentration of $\mathrm{PM}_{0.3}$ obtained ranging between (79.85 - 269.49) $\mu \mathrm{g} / \mathrm{m}^{3}$ in Phase 1 , and ranging between $(273.49-352.85) \mu \mathrm{g} / \mathrm{m}^{3}$ in Phase 2. The increased of the daily average concentration of $\mathrm{PM}_{0.3-\infty}$ within a week is nearly doubled from Phase 1 to Phase 2 as increased by $95.08 \%$ which from averaged value of $(164.30 \pm 158.33)$ $\mu \mathrm{g} / \mathrm{m}^{3}$ to $(320.52 \pm 138.00) \mu \mathrm{g} / \mathrm{m}^{3}$. With the range of $(9.52-$ $28.84) \mu \mathrm{g} / \mathrm{m}^{3}$ in daily average concentration of $\mathrm{PM}_{0.5}$ during Phase 1 , it had increased to a higher range of $(24.31-44.01)$ $\mu \mathrm{g} / \mathrm{m}^{3}$ during Phase 2. The increment of the daily average concentration of $\mathrm{PM}_{0.5}$ within a week from Phase 1 to Phase 2 is denoted with $103.94 \%$ which from averaged value of $(16.77 \pm 17.00) \mu \mathrm{g} / \mathrm{m}^{3}$ to $(34.20 \pm 18.71) \mu \mathrm{g} / \mathrm{m}^{3}$. For the daily average concentration of $\mathrm{PM}_{1}$ that ranged between $(0.96-$ 5.27) $\mu \mathrm{g} / \mathrm{m}^{3}$ in Phase 1 and $(7.08-12.61) \mu \mathrm{g} / \mathrm{m}^{3}$ in Phase 2, significant increment of the concentration is observed. There is soar up of more than two times, that increase of around $226.55 \%$ in the daily average concentration of $\mathrm{PM}_{1}$ within a week from Phase 1 to Phase 2 which from averaged value of $(2.90 \pm 2.07) \mu \mathrm{g} / \mathrm{m}^{3}$ to $(9.47 \pm 11.38) \mu \mathrm{g} / \mathrm{m}^{3}$. In Phase 1 , the daily average concentration of $\mathrm{PM}_{2}$ has ranged between $(0.48$ - 2.21) $\mu \mathrm{g} / \mathrm{m}^{3}$ in Phase 1 and $(3.50-4.72) \mu \mathrm{g} / \mathrm{m}^{3}$ in Phase 2 . The daily average concentration of $\mathrm{PM}_{2}$ within a week from Phase 1 to Phase 2 has increased from averaged value of $(1.36 \pm 0.86) \mu \mathrm{g} / \mathrm{m}^{3}$ to $(4.06 \pm 3.22) \mu \mathrm{g} / \mathrm{m}^{3}$. It had increase for $198.53 \%$. Overall, Phase 1 showing great fluctuation on the concentration of $\mathrm{PM}_{0.3}$ except during D4. Data collected showing that in Phase 1; the wind speed is relatively higher than in Phase 2. Thus, a more windy condition in Phase 1 causing the unsteadiness, as the concentration of particulate matter in the atmosphere is highly associated with wind speed according to [23]. Wind speed affecting the accumulation, diffusion, dilution and accumulation of particulates in the atmosphere [24]. During D3 of Phase 1, the particulate matter concentrations with different sizes are all showing lower value than during D1, D2 and D4. This caused by the heavy rain event that happened a day before D3. The rain had caused the removal of particulates and washed off the pollutants that suspended in the atmosphere. The construction activities carried out during Phase 2 principally causing the concentration of particulate matter in Phase 2 is significantly higher. Examples of activities on the construction work site including reinforcing concrete, lifting of masonry and plastering has more expressively producing elements such as $\mathrm{Ca}, \mathrm{Si}, \mathrm{Cl}, \mathrm{Al}$ and $\mathrm{Fe}$ [25].

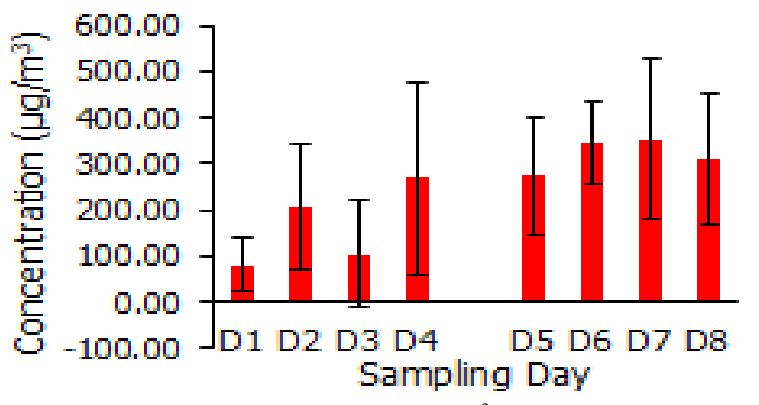

Fig. 1. The average concentration of $\mathrm{PM}_{0.3}\left(\mu \mathrm{g} / \mathrm{m}^{3}\right)$ for each sampling day.

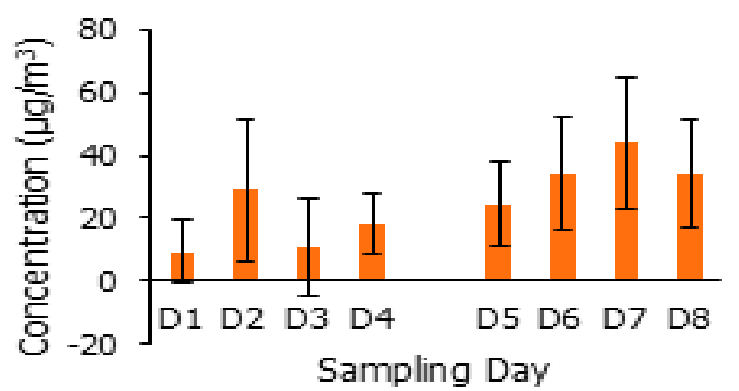

Fig. 2. The average concentration of PM0.5 $\left(\mu \mathrm{g} / \mathrm{m}^{3}\right)$ for each sampling day.

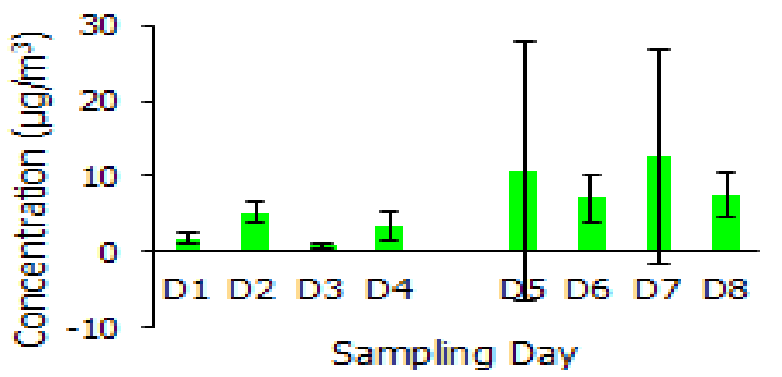

Fig. 3. The average concentration of PM1 $\left(\mu \mathrm{g} / \mathrm{m}^{3}\right)$ for each sampling day.

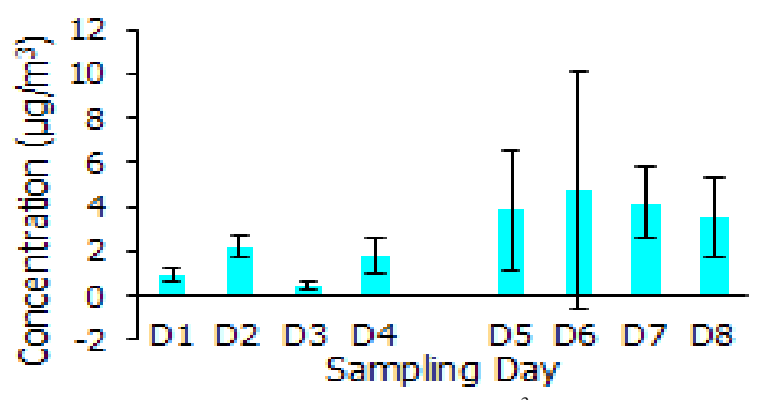

Fig. 4. The average concentration of PM2 $\left(\mu \mathrm{g} / \mathrm{m}^{3}\right)$ for each sampling day.

\section{CONCLUSIONS}

The airborne particulate concentration $\left(\mathrm{PM}_{0.3}, \mathrm{PM}_{0.5}, \mathrm{PM}_{1}\right.$ and $\mathrm{PM}_{2}$ ) around the construction site during construction activities were carried out which showed PM emission is mostly sourced by the superstructure construction activities. Thus, higher PM concentration is collected throughout Phase 2. The daily averaged PM concentration within a week had increased $95.08 \%$ for $\mathrm{PM}_{0.3}, 103.94 \%$ for $\mathrm{PM}_{0.5}, 226.55 \%$ for $\mathrm{PM}_{1}$ and $198.53 \%$ for $\mathrm{PM}_{2}$ from Phase 1 to Phase 2. Higher emissions from the construction equipment and machineries, and the movement of vehicles are also contributes to the higher ambient PM concentration in Phase 2. Though, owing to the size and the complexity of the construction site, overlapping of construction activities 
happening may also influence the PM concentration. The meteorological parameters are also monitored throughout the air sampling. Weather condition influenced the airborne particulate through the reactions within the atmosphere, affected their dispersion and concentration. Result showed that the relative humidity and wind speed is higher in Phase 1 (during wet season) than in Phase 2 (during dry season), whereas, the temperature is higher during dry season. The correlation analysis between different sizes of PM concentration with both relative humidity and temperature show strong relationships where $\mathrm{R}$ value range from -0.53749 to -0.78428 and 0.76013 to 0.95546 .

\section{REFERENCES}

[1] C. Yoon, K. Lee, and D. Park, "Indoor air quality differences between urban and rural pre-schools in Korea," Environment Science Pollution Research, vol. 18, pp. 333-345, 2011.

[2] S. Almeida, N. Canha, A. Silva, M. Freitas, Pegas et al., "Children exposure to atmospheric particles in indoor of Lisbon primary schools," Atmospheric Environment, vol. 45, pp. 7594-7599.

[3] P. Branco, M. Alvin-Ferraz, F. Martins, and S. Sousa, "Indoor air quality in urban nurseries at Porto city: Particulate matter assessment," Atmospheric Environment, vol. 84, pp. 133-143, 2014.

[4] R. Nunes, P. Branco, M. Alvin-Ferraz, F. Martins, and S. Sousa, "Particulate matter in rural and urban nursery schools," Portugal Environmental Pollution, vol. 202, pp. 7-16, 2015.

[5] W. Yang, J. Sohn, J. Kim, B. Son, and J. Park, "Indoor air quality investigation according to age of the school buildings in Korea," Journal of Environment Management, vol. 90, pp. 348-354, 2009.

[6] A. Valavanidis, K. Fiotakis, and T. Vlachogianni, "Airborne particulates matter and human health: toxicological assessment and importance of size and composition particles for oxidation damage and carcinogenic mechanisms," Journal of Environmental Science and Health Environmental Carcinogenic Ecotoxicological Review, vol. 26, no. 4, pp. 339-362, 2008.

[7] P. Wolkoff and S. Kjærgaard, "The dichotomy of relative humidity on indoor air quality," Environmental International, vol. 33, pp. 850-857, 2007.

[8] I. P. S. Araujo, D. B. Costa, and R. J. B. Moraes, "Identification and characterization of particulate matter concentrations at construction jobsites," Sustainability, vol. 6, pp. 7666-7688, 2014.

[9] B. Chen, J. Chen, J. Zhao, and F. Zhang, "Particulate air pollution from combustion and construction in coastal and urban areas of China,' Journal of the Air and Waste Management Association, vol. 61, no. 11, pp. 1160-1165, 2011.

[10] S. K. John, J. L. Kara, C. S. William, E. M. Gregory, and C. Chatten, "Characterization of the fugitive particulate emissions from construction mud/dirt carryout," Journal of the Air \& Waste Management Association, vol. 54, no. 11, pp. 1394-1404, 2004.

[11] J. Qi, A. Nadhir and K. Sven, "Measurement of dust emission from a road construction using exposure-profiling method," Natural Science, vol. 5, no. 12, pp. 1255-1263, 2013.

[12] A. C. Rohr and R. E. Wyzga, "Attributing health effects to individual particulate matter constituents," Atmospheric Environment, vol. 62, pp. 130-152, 2012.

[13] P. Vinzents, P. Moller, M. Sorensen, L. Knudsen, O. Hertel et al., "Personal exposure to ultrafine particles and oxidative DNA damage," Environmental Health Perspectives, vol. 113, no. 11, pp. 1485-1490, 2005.

[14] K. Ito, W. F. Christensen, D. J. Eatough, R. C. Henry, E. Kim et al., "PM source apportionment and health effects: 2. An investigation of intermethod variability in associations between source-apportioned fine particle mass and daily mortality in Washington, DC.," Journal of Exposure Science and Environmental Epidemiology, vol. 16, pp. 300-310, 2006.

[15] T. F. Mar, K. Ito, J. Q. Koenig, T. V. Larson, D. J. Eatough et al., "Investigation of inter-method variations in associations between estimated source contributions of PM2.5 and daily mortality in Phoenix, AZ.," Journal of Exposure Science and Environmental Epidemiology, vol. 16, pp. 311-320, 2006.

[16] S. Cakmak, R. E. Dales, and C. B. Vida, "Components of particulate air pollution and mortality in Chile," International Journal of Occupational and Environmental Health, vol. 15, pp. 152-158, 2009.

[17] K. S. Richardson, A. Kuenzi, R. J. Douglass, J. Hart, and S. Carver, "Human exposure to particulate matter potentially contaminated with Sin Nombre virus," International Association for Ecology and Health, vol. 10 , no. 2 , pp. 159-165, 2013.

[18] Malaysian Meteorological Department (MetMalaysia). (2013). General Climate of Malaysia. [Online]. Available: http://www.met.gov.my/index.php?option=com_content\&task=view\& id=75\&Itemid $=1089$ \&limit $=1$ \&limitstart $=0$

[19] C. Pillinis and J. H. Seinfeld, "Development and evaluation of an aulerian photochemical gas-aerosol model," Atmospheric Environment, vol. 22, pp. 1985-2001, 1988.

[20] A. J. Fadi, A. K. Entisar, and A. O. Muthanna, "Concentrations of particulate matter and their relationships with meteorological variables," Sustainable Environment Research, vol. 23, no. 3, pp. 191-198, 2013.

[21] A. G. Megaritis, C. Fountoukis, P. E. Charalampidis, C. Lipinis, and Pandis, "Response of fine particulate matter concentrations to changes of emissions and temperature in Europe," Atmospheric Chemistry and Physics, vol. 13, pp. 3423-3443, 2012.

[22] B. V. Bogdana, M. V. Srdan, V. V. Goran, M. J. Nebojsa, R. J. Gordana, and J. B. Milun, "Experimental and artificial neural network approach for forecasting of traffic air pollution in urban areas: the case of Subotica," Thermal Science, vol. 14, S79-S87, 2010.

[23] M. Pascal, G. Falq, V. Wagner, E. Chatignoux, M. Corso et al., "Short-term impacts of particulate matter (PM10, PM10-2.5, PM2.5) on mortality in nine French cities," Atmospheric Environment, vol. 95, pp. $175-184,2014$.

[24] S. E. Kim, Y.-H. Lim, and H. Kim, "Temperature modifies the association between particulate air pollution and mortality: A multi-city study," South Korea. Science of the Total Environment, pp. 524-525, pp. 376-383, 2015.

[25] J. A. Sarnat, A. Marmur, M. Klein, E. Kim, A. G. Russell et al., "Fine particle sources and cardiorespiratory morbidity: An application of chemical mass balance and factor analytical source-apportionment methods," Environmental Health Perspectives, vol. 116, pp. 459-466, 2008 .

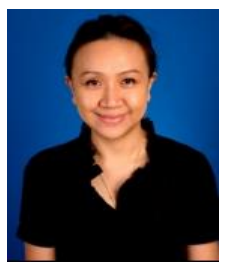

Carolyn Payus is a senior lecturer in Universiti Malaysia Sabah (UMS) for environmental science programme since year 2005. Her research interest mainly on atmospheric chemistry, water resource governance, environmental monitoring, assessment and restoration.

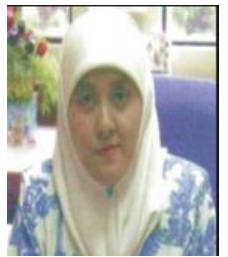

Norela Sulaiman is an associate professor from Universiti Kebangsaan Malaysia (UKM) and her expertise is in air pollution, zoology and life cycle assessment at production system for environment. 